widespread in Britain. It seems necessary to postulate the existence of cofactors. There is no evident explanation for the rarity of the disease in western Eire.

We are most grateful to the radiologists and other staff in the radiology departments of the Mater Misericordiae Hospital, Dublin, and the Merlin Park Hospital, Galway. The study was supported by the Medical Research Council, the National Association for the Relief of Paget's Disease, and the Rehabilitation and Medical Research Trust.

${ }^{1}$ Detheridge FM, Guyer PB, Barker DJP. European distribution of Paget's disease of bone. $\mathrm{Br} \mathrm{Med} \mathcal{F} 1982 ; 285: 1005-8$.

${ }^{2}$ Barker DJP, Chamberlain AT, Guyer PB, Gardner MJ. Paget's disease of bone: the Lancashire focus. $\mathrm{Br}$ Med $\mathcal{F} 1980 ; 280: 1105-7$.

${ }^{3}$ Rebel A, Basle M, Pouplard A, Kouyoumdjian S, Filmon R, Lepatezour A. Viral antigens in osteoclasts from Paget's disease of bone. Lancet 1980 ;ii :344-6.

(Accepted 6 fuly 1983)

MRC Environmental Epidemiology Unit, Southampton General Hospital, Southampton SO9 4XY

F M DETHERIDGE, BSC, MSC, research fellow

D J P BARKER, PHD, FRCP, professor of clinical epidemiology

Department of Radiology, Southampton General Hospital, Southampton SO9 $4 \mathrm{XY}$

P B GUYER, DM, FRCR, consultant radiologist

Correspondence to: Professor D J P Barker.

\section{Perforation of a bronchus due to electrical injury}

We report a case of electrical injury that occurred under unusual circumstances and led to bronchial perforation, mediastinal emphysema, and pneumothoraces. Despite severe bronchial mucosal damage the patient quickly made a full recovery. Pulmonary complications after electrical injury are well documented, ${ }^{12}$ but this pattern of injury has not, to our knowledge, been noted before.

\section{Case report}

A previously fit 21 year old motor mechanic was admitted to a casualty department with severe chest pain and respiratory distress. He later described the events that had led to his injury. While working with a grinding tool he salivated through an air vent in the machine casing on to a live terminal. He noticed a blue flash that entered his mouth; he was then thrown away from the tool and was immediately aware of chest pain, difficulty in breathing, and swelling of his face.

On admission to the casualty department cyanosis, haemoptysis, and surgical emphysema of head and neck were apparent. Fresh blood was noted in his mouth. The upper airway was patent, and bilateral pneumothoraces were confirmed by $x$ ray examination. Circulation was stable, and no other injuries were apparent. Intercostal drains were inserted, with some improvement in breathing pattern. He was then transferred to this intensive care unit.

Repeat $x$ ray examinations showed partial re-expansion of both lungs, severe bilateral pulmonary shadowing suggesting pulmonary oedema, mediastinal emphysema, and massive gastric dilatation. Artificial ventilation was necessary because of respiratory failure due to severe pulmonary oedema and the large quantity of analgesia required for adequate pain relief. The programme of intermittent positive pressure ventilation followed methods that are standard to this unit. ${ }^{3}$ Over the next 48 hours the hypoxaemia worsened and lung compliance decreased. The alveolar arterial pressure gradient for oxygen was $45.7 \mathrm{kPa}(343 \mathrm{~mm} \mathrm{Hg})$ (10 times the control value of $2 \cdot 9-5 \cdot 9 \mathrm{kPa}(22-44 \mathrm{~mm} \mathrm{Hg}))$.

Copious amounts of bloodstained tracheal aspirate were produced. Fibreoptic bronchoscopy showed blackened and haemorrhagic mucosa with necrotic slough. A perforation in the wall of the left main bronchus was noted, $2 \mathrm{~cm}$ distal to the carina. This had a base of necrotic tissue, suggesting that the perforation had sealed off.

The tracheal aspirate decreased over the next six days, and gas exchange improved. The lung fields cleared, and the mediastinal emphysema resolved. Repeat bronchoscopy showed healthy regenerating bronchial mucosa with healing at the site of the perforation. On day 10 he was successfully weaned from the ventilator. A further problem was hypercatabolism with a urinary nitrogen loss in excess of $3.2 \mathrm{~mol}(45 \mathrm{~g})$ a day; this was managed with intravenous feeding. He was discharged 12 days after admission and remained well, with no evidence of bronchial stenosis.

\section{Comment}

Pulmonary complications of electrocution are well known and include haemorrhage necrotising tracheobronchitis, ${ }^{4}$ staphylococcal pneumonia, ${ }^{1}$ pneumonitis, atelectasis, and pleural effusions. ${ }^{2}$ Although one case of bronchopleural fistula with empyema has been described, the findings in our case are new.

We believe that electrical current (110 volts, alternating current, delivered through a transformer) passed up the salivary stream into the mouth and continued down the trachea into the left main bronchus. There a perforation was formed as it entered the mediastinum. This produced mediastinal emphysema, bilateral pneumothoraces, and surgical emphysema of head and neck.

We accept that this is an unusual injury and that the current usually delivered by such a machine is not of the magnitude associated with severe electrical injury. We have, however, sought alternative explanations and fully discussed the matter with the medical adviser of the Health and Safety Executive. The extremely old machine may possibly have been delivering a current in excess of that calculated, but unfortunately it was disposed of after the initial factory inspection and this theory cannot be tested. The patient's account was substantiated by the foreman who found him, and as neither stood to gain financially we see no reason why they should invent this story.

In addition, the unusual features of this case are the presence of a spontaneously healing bronchial perforation and severe pulmonary parenchymal damage that resolved rapidly with artificial ventilation. This was without recourse to specialised techniques such as surgical repair of the bronchus or differential lung ventilation.

1 Divincenti FC, Moncrief JA, Pruitt BA Jr. Electrical injuries: a review of 65 cases. F Trauma $1969 ; \mathbf{9}: 497-507$.

${ }^{2}$ Butler ED, Gant TD. Electrical injuries, with special reference to the upper extremities. A review of 182 cases. Am f Surg 1977;134:95-101.

${ }^{3}$ Jones ES. Essential intensive care. Lancaster: MTP Press, 1978:246-70.

4 Taylor PH, Pugsley LQ, Vogel EH. The intriguing electrical burn. A review of 31 electrical burn cases. $\mathcal{F}$ Trauma 1962;2:309-26.

(Accepted 20 fuly 1983)

Intensive Care Unit and Clinical Research Laboratory, Whiston

Hospital, Prescot, Merseyside L35 5DR

C S BOWLER, MRCP, medical registrar

I J GORDON, MRCP, medical registrar

Correspondence to: Dr C S Bowler.

\section{Acne vulgaris and hidradenitis suppurativa as presenting features of acromegaly}

Production of sebum is of major importance in the pathogenesis of acne vulgaris ${ }^{1}$ and is increased in acromegaly. ${ }^{2}$ The two diseases have only rarely been associated, but we report on two patients in whom acne vuigaris was the presenting feature of acromegaly; both also developed hidradenitis suppurativa.

\section{Case reports}

Case 1-A 30 year old man presented with a two year history of severe nodulocystic acne of the face, with milder acne of the back and chest, and hidradenitis suppurativa affecting the groin and left axilla. He had had mild acne as an adolescent but had subsequently been free from active disease for several years. Besides these skin changes and mild Raynaud's phenomenon he had obviously acromegalic features and his shoe size had increased from 10 to 12 over the previous two years. Acromegaly was confirmed, and there was evidence of a small pituitary tumour. Growth hormone concentrations $(19 \cdot 2 \mathrm{mU} / \mathrm{l})$ failed to decrease appreciably after oral glucose. Basal gonadotrophin concentrations were normal but did not rise in response to gonadotrophin releasing hormone. Serum concentrations of testosterone and prolactin were $10 \mathrm{nmol} / 1(2.9 \mathrm{ng} / \mathrm{ml})$ (normal $10-30 \mathrm{nmol} / 1)(2 \cdot 9-8 \cdot 7 \mathrm{rg} / \mathrm{ml})$ ) and $166 \mathrm{mU} / 1$ (normal $<425 \mathrm{mU} / \mathrm{l}$ ) respectively. As he was unable to tolerate bromocriptine, pergolide mesylate $50 \mu \mathrm{g}$ daily was administered and suppressed growth hormone concentrations satisfactorily (to $2 \cdot 2 \mathrm{mU} / 1$ ) while hypophysectomy was considered. Minocycline controlled the acne, but the hidradenitis remained active.

Case 2-A 24 year old man had developed mild acne at the age of 14 . 
From the age of 18 this had become gradually more severe, and he had observed progressive coarsening of his features. At referral he was noted to have severe facial acne and acromegalic features. Acromegaly was confirmed by basal growth hormone concentrations of $16 \cdot 7-20 \mathrm{mU} / 1$, which failed to decrease after oral glucose. Serum concentrations of luteinising hormon $(4 \mathrm{U} / \mathrm{l})$ and follicle stimulating hormone $(3 \mathrm{U} / \mathrm{l})$ rose to $12 \mathrm{U} / 1$ and $14 \mathrm{U} / \mathrm{l}$ respectively in response to gonadotrophin releasing hormone. Serum concentrations of testosterone $(21.6 \mathrm{nmol} / 1(6.2 \mathrm{ng} / \mathrm{ml}))$ and prolactin (295 mU/l) were normal. Attempted surgical removal of a suprasellar pituitary adenoma only partially suppressed secretion of growth hormone (to $13.6-14.6 \mathrm{mU} / 1$ ); because medical treatment also failed to give adequate control external radiotherapy (4000 rads) was given. Meanwhile his acne remained active, the acromegaly became more gross, and he developed hidradenitis suppurativa of the left axilla and perineum.

\section{Comment}

Patients with acromegaly often have a greasy skin and, in common with patients with severe acne, ${ }^{1}$ have a greatly increased rate of excretion of sebum. ${ }^{2}$ Acne is not, however, a recognised feature of acromegaly and, as in a recent British study of 155 patients with acromegaly, ${ }^{3}$ is not mentioned in most reviews of the disease. Severe acne was present in three of 35 Polish patients with acromegaly reported on in $1968,{ }^{4}$ and one French report described a 49 year old woman with acromegaly who presented with rapidly progressive nodulocystic acne. ${ }^{5}$ Acne thus appears to be a surprisingly uncommon feature of acromegaly. Hidradenitis suppurativa may accompany severe acne, but the influence of endocrine factors on this condition has received scant study. We suggest that the pituitary endocrine abnormalities in our patients were important in the aetiology of their skin disease and, therefore, that acromegaly may on occasion present with severe acne vulgaris.

1 Cotterill JA, Cunliffe WJ, Williamson B. Severity of acne and sebum excretion rate. $\mathrm{Br} \mathcal{F}$ Dermatol $1971 ; 85: 93-4$

2 Burton JL, Libman LJ, Cunliffe WJ, Wilkinson R, Hall R, Shuster S Sebum excretion in acromegaly. Br Med $\mathcal{F} 1972 ; \mathrm{i}: 406-8$.

3 Jadresic A, Banks LM, Child DF, et al. The acromegaly syndrome: relation between clinical features, growth hormone values and radiological characteristics of the pituitary tumours. $Q \mathcal{F}$ Med 1982;51 189-204.

4 Materlik H, Słowko T, Jedrzejczak A. Skin changes in acromegaly. Pol Med F 1968;7:1522-7.

5 Pinetti P. Acné conglobata à forme fruste, constituée par d'innombrables comédons et petits kystes sébacés à contenu huileux, par des clapiers fistulisés, des cicatrices en pont, des formations fibreuses, chez une malade basedowienne, acromégalique, avec tumeur hypophysaire probable. Annales de dermatologie et de syphiligraphie 1936;7:245-61.

(Accepted 12 July 1983)

\section{Skin Hospital, Manchester M3 3HL}

R J G CHALMERS, MRCP, senior registrar

R D EAD, MRCP, consultant dermatologist

M H BECK, MRCP, consultant dermatologist

University of Manchester School of Medicine, Hope Hospital, Eccles, Manchester M6 8HD

$P$ DEWIS, MRCP, tutor in medicine

D C ANDERSON, MD, FRCP, senior lecturer in medicine

Correspondence to: Dr R J G Chalmers.

\section{Obscure splenomegaly in the tropics that is not the tropical splenomegaly syndrome}

The tropical splenomegaly syndrome originally referred to cases of splenomegaly in the tropics for which no cause was found even after full investigation. ${ }^{1}$ Since then it has come to refer specifically to a condition resulting from an aberrant immunological response to malaria. ${ }^{2}$ Criteria for diagnosis include immunity to malaria, raised serum IgM concentrations, response to antimalarial drugs, and hepatic sinusoidal lymphocytosis on liver biopsy. ${ }^{3}$ Patients with undiagnosed splenomegaly were studied to see whether these criteria were fulfilled and whether malaria was aetiologically relevant in all cases.

\section{Patients, methods, and results}

Altogether 131 adult patients with chronic splenomegaly were investigated at Kenyatta National Hospital, Nairobi. They were allocated to diagnostic groups on the basis of clinical, haematological, and parasitological findings and the results of liver biopsy. The tropical splenomegaly syndrome and hepatosplenic schistosomiasis were diagnosed specifically on the results of liver biopsy, and visceral leishmaniasis on the results of splenic aspiration. In this way 41 patients were considered to have the tropical splenomegaly syndrome, 23 hepatosplenic schistosomiasis, and seven visceral leishmaniasis. Specific, less common, diagnoses were made in 44 cases and included haematological disorders and lymphomas, liver disease with portal hypertension, tuberculosis, sarcoidosis, heart failure, and malaria. In 16 patients no diagnosis was reached. In these patients, whom we diagnosed as having "indeterminate splenomegaly," examination was inconclusive, periphera blood films showed no relevant abnormality, results of liver biopsy were non-diagnostic, barium swallow or endoscopy, or both, did not show oesophageal varices, and visceral leishmaniasis was excluded on results of splenic aspiration or geographical background. Only one patient $(6.7 \%)$ in this group had ova of Schistosoma mansoni detected on examination of stools or rectal snip, compared with $17(73.9 \%)$ of those with histologically diag nosed hepatosplenic schistosomiasis $(\mathrm{p}<0.001)$

Malarial antibody titres were determined by an indirect fluorescence antibody test ${ }^{4}$ and IgM concentrations by kinetic turbidimetry. ${ }^{5}$ The table compares results in patients with the tropical splenomegaly syndrome and those with indeterminate splenomegaly.

Results of malaria indirect fluorescence antibody test (IFAT) and estimation of IgM concentrations in patients with the tropical splenomegaly syndrome and indeterminate splenomegaly

\begin{tabular}{lccc}
\hline & $\begin{array}{c}\text { Tropical } \\
\text { splenomegaly } \\
\text { syndrome } \\
(\mathrm{n}=38)\end{array}$ & $\begin{array}{c}\text { Indeterminate } \\
\text { splenomegaly } \\
(\mathrm{n}=15)\end{array}$ & p value \\
\hline Mode of IFAT titre & $1 / 4096$ & $1 / 256$ & \\
$\begin{array}{l}\text { No }(\%) \text { with IFAT titre of } 1 / 1024 \\
\text { or greater }\end{array}$ & $35(92.1 \%)$ & $4(26.7 \%)$ & $<0.001$ \\
$\begin{array}{l}\text { Geometric mean IgM (g/1) }(95 \% \\
\text { confidence limits for geometric } \\
\text { mean) }\end{array}$ & $4.9(0.7-33.7)$ & $1.6(0.4-7 \cdot 1)$ & $<0.001$ \\
\hline
\end{tabular}

Four patients with indeterminate splenomegaly had titres of $1 / 1024$ or above on indirect fluorescence antibody testing, with $\operatorname{IgM}$ concentration $2 \mathrm{SDs}$ above the local mean in one case and $1 \mathrm{SD}$ above the local mean in two cases. In the patient with the highest $\operatorname{IgM}$ concentration regression of splenomegaly occurred with proguanil $100 \mathrm{mg}$ once daily. In the only other four patients followed up for at least six months no response to proguanil was observed.

\section{Comment}

The patient with the highest IgM concentration and a high malarial antibody titre who responded to proguanil probably had the tropical splenomegaly syndrome without the changes characteristically found on liver biopsy. The same may possibly apply to the two other patients with high titres and IgM concentrations $1 \mathrm{SD}$ above the local mean. For the other patients with indeterminate splenomegaly, however, the low malarial antibody titres, low IgM concentrations, non-diagnostic liver biopsies, and failure to respond to proguanil in those followed up make the tropical splenomegaly syndrome an unlikely diagnosis. There was no evidence in these patients of any other specific condition, and we are forced to conclude that cases of obscure splenomegaly that are distinct from the tropical splenomegaly syndrome still occur in the tropics.

These findings emphasise that the tropical splenomegaly syndrome cannot be diagnosed by exclusion alone. There is a need for discussion and agreement about diagnostic criteria. Finally, as the tropical splenomegaly syndrome is now accepted to have a malarial aetiology, perhaps the time has come to abandon this confusing term in favour of one that is more specific and informative.

We are grateful to Professor Michael Hutt for advice and discussion and to the Wellcome Trust for financial support. We thank Dr R Raja, Dr V Talwar, and Dr S Thomas for help with radiology and endoscopy. Dr C Draper and staff, London School of Hygiene and Tropical Medicine, kindly advised on malarial serology.

${ }^{1}$ Anonymous. Tropical splenomegaly syndrome. $\mathrm{Br} M e d \mathcal{f} 1967$;iv:614.

${ }^{2}$ Marsden PD, Crane GG. The tropical splenomegaly syndrome. A current appraisal. Rev Inst Med Trop Saõ Paulo 1976;18:54-70. 